\title{
Start with the street, the voice said
}

This text offers a writing experiment that aims to address the processes of gentrification. It employs a narrative mode of writing in the first person plural in order to demonstrate one possible way of capturing the complexities of everyday experiences of metropolitan conditions. The text challenges the assumed notions of authorial voice and supposed analytical objectivity of (academic) critique and proposes a way of tackling the ambiguities that lie at the core of the relationship forged between urban subjects and objects that partake in the flows of capitalism. The accompanying photographs, while depicting of some of the places described (Bermondsey Street, London, UK) are not literal illustrations. The readers are encouraged to forge their own connections.

Keywords: fiction; gentrification; Bermondsey Street; London

And so we did. We left the flat and locked the door and walked to the lift and hailed it, and as we waited we watched October light draw blood from the leaves outside: how obscure the section - a glass, a tree - of the screen that envelops the staircase, it's milky glass, it's grid-grid-grid, and it turns the sight into a painting. Or not a painting, a photograph perhaps, that's it. But we are inside the lift already, and it's - what, this surface? - textured and lit, and there is a mirror at the back, image beyond the image, and we can see ourselves in it. We look a bit tired perhaps, a bit older than we did but that's fine, we can live with it, we might even blow ourselves a kiss - reflected - but in the end, we don't. Not today. And by the time the lift has stopped moving, and the balls in our feet are no longer compensating, the door will open and we'll brace ourselves for someone, anyone, standing outside it. One of the neighbors perhaps (this one, or that one, and we'd really hate to run into that git) but there is no one outside, nothing to see, just the light of this star touching the tiling. How old, this floor, as old as the building? It's something we should know, we could summon the council. But we won't. We don't ask since we don't care, not enough at least. There are other things that demand thinking.

And so out the door we go - press that button release - then one, two, three, four, five and step six, we are past the entranceway where we could have faced a dog and two little boys, and a woman with a sour little, plump little face, who squeaks in response to 
our hello every time, which - in truth - we offer rarely. But they are not there now, we can't see them, can we. And we can't help but glance back, the sneakiest little glance from under the lid, to confirm that the door to the garden - what would you even call that thing? - is locked, and the blinds are drawn, and we are on the pavement, where it's all official and safe. We have cleared the zone of potential conflict.

So down the block we trot, down this stretch of the street, there is perhaps a fifteensecond journey in it. Is there anyone watching us enter the scene? Is there a cook smoking on the other side - there is one sometimes, sometimes there's three - as we pass the rent-a-bikes, the little solider bikes - position up, lock in - and then it's the corner, the edge of our street, where we try and gauge what's coming from the left, what might hit us from behind, try and guess what lies ahead where the street bends and hides from our eye, as if to conceal something. As if.

But we know what's coming, we've been here a number of times. It's been a decade now, years indeed, of dancing inside this container of bodies, so we recognize the moment, we might even greet it; we cross and swerve around the corner of a building (once so different, a layer of peel only to cover it), and we cast a glance across, we shoot that glance diagonally, only for its arrow to land - on a cake. We have a memory of being inside this building - what is it, what was it, not the cake, the edifice, something special indeed, a watch house, that's it - on the edge of the park, a cake place with single origin coffee only, where you are free to sit (if you are careful about what you do with your feet, if you appreciate the varnish and the crumbs you lick) and do only what you are supposed to do, which is, of course, eat cake. Red it was - oh how we remember it - with icing to crown the crumbly bit. And it was such a treat. But we rip our gaze from the cake thus framed - no cake for us, not today - because we keep walking and the steps we make (and we keep making step after step after step each day) will rip what the skin of our eyes has collected. And since we keep moving, we can't stop moving, we will brush our shoulders - the left one only? - against the fronts of shops instead of dwelling on anything; very particular shops, very mhmmm and ah-haaa shops, shops that burst onto the street with - what? - we know not what. Precociousness, perhaps. Refinement and dignity. They are in possession of a certain spirit, certain genius. Loci indeed. 
There was a morning here once, right there, inside, and there was a man behind a desk (most certainly) and we were in such a hurry, we had to have a card, any card really, but he was taking-his-precious-time, he was speaking ever-so-slowly, and for a moment we thought we'd storm right out; we thought we'd lose it. We'd slam the door. Or leave it open, deliberately. But we didn't - of course not, how could we? - so instead, we waited patiently. And had this taken place somewhere else (where the sun rises) we would have bowed deep-deep, our back perfectly straight. As it was, we thanked him profusely and left the shop on the tips of our toes - oh yes, we did - and there was a smile on our face, a smile of such magnitude that it hurt our cheeks. All of our cheeks. Oh yes, it did.

But we are already next door, another shop tempting our feet - a collection of collections this street, a collection ad nauseam it is - no cake inside, an explosion of flowers instead (indeed), flowers particular and expensive, couched in wines and chocolates sat pretty, and we recall hearing how hard it was to make money - oh, how hard, it's not what you'd think! - how hard it is on this, our beloved street, where rents are exorbitant and costs pile up high and, well, you can't always count on bodies to be chasing the till. Since despite all the faces signaling thrill, all the faces delighted to have a window to stare in (such tasteful arrangements, such rustic chic) there are only a few customers ever that dare go in. But how satisfying, how truly fulfilling, to be offering Top! Range! Product!, the owner had claimed - us, friends with him? - how critical to offer expensive wines, on this, our beloved street. So. We cast a glance, then tear it away. And we are already passing the next place by, where our eyes swerve to take the window in, and inside it they find... a bunch of sticks. Sparkly they are - not the season but why hair/split? - for the perpetual festival that take place in it. Because everything on this street, everything on our magnificent street, everything on our darling little village street straight in the middle of the city, is a cause to summon the spirit of joy. Or, not a cause, an opportunity. And if that's what we aim for, by god, will we arrive eventually.

But off we go past the third window sliding, where our eyes discover they can hold not a thing. It's what happens when you leave your audience to stare (unlit) and all that can be found is a silhouette fleeting, as they chop whatever it is they must chop today. Banal, utterly. But who knows, perhaps. Perhaps excitement, perhaps intrigue. And anyway, someone was murdered on this street, they say. A woman, Portuguese we think 
- or was she Spanish? - or was the eatery Spanish and she was Italian? - an Italian cockney, you think? - or someone else altogether was done in - we are getting feverish, we are getting confused, we are, aren't we? - but then again, it's just folklore and myth, Tales of Adventure and Wonder on this, our beloved street. And if we had it in our little hearts to try, if we had it in our hearts to really, truly try, we'd know how to get to the bottom of it. But we don't, do we; we don't care enough to dig. We are king of impressions fleetingly made.

So off we go, we are moving on with it. There is a shift in geometry and, oh, how our heart skips a beat. The texture of our walk changes, this walk that - let's face it - is nothing but ourselves being alive to ourselves moving. And as the angle nears and we decide to face it, we stumble upon the edge - not us, our eyes - what we'll pivot around: a building-edge, all ochre and strict and neatly laid. It's weft, this brick, it's whatever you ask of it, it's playful and regimented and a few extras with it. But we are already past it, past the fish bowl vitrine, where every day except Closed on Mondays we have seen suit after suit after suit come in and eat. And it's not Italian this, no. Even if it's Best Italian in London (guaranteed), even if it's this star and that star and that vehicle tire company catalogue thing. But suits, do they just come. And do they eat their swordfish on a bed of roses, their crispy fried pumpkin leaves, their pasta with, well, pasta paint. They eat and eat - the suits do, don't they? - morsel after morsel, bite after bite, it all disappears between their moist lips. They simply know how to...hmmm. Live?

But why are we even speaking of it in such detail? We are elsewhere already and we keep walking, we walk all the time - we do, don't we? - because walking will get us anywhere, it seems. Perhaps. A few more steps and, perhaps because the void cracks open at that particular point, we catch ourselves glance to the other side, to the figures in fashions and limbs in drapes, and beards thoroughly beardy. This is when we spot that little girl we see every day, the smallest, littlest girl we greet - the tiniest of tiny girls! - with her chirpy voice and her lovely smile, who is at that very moment smoking and reading, i.e., Ignoring. Everyone. On. Her. Lunch. Break.

It is this girl that we will remember for longer than our eyes hold on to sight. It is this girl that we'll commit to memory (layer upon layer upon layer of it). It is this girl, who 
we don't know, who we'll never know - and why would we, why should we, would we even want to, not really - whose face will remain deposited like silt, like mud-becomerock-become-landscape, with all the mornings we'd ordered our coffee, and all the occasions we'd noted her eye, and looked at her round little shoulder - squeeze! - and tiny little hands that hand us our coffee, and stamp the card of loyalty, and take our money to where no one can see it. We are lost inside the girl's eye, her glass figurine eye, as we recall all of this in the moment it takes us to pass the café and avert our eye, and progress on the stealers' raid of the street where we live.

And off we go, we continue on, to a gallery that's all neon and concrete, all runway interstellar and art larger than life. It exists in the way we exist sometimes, which is to say - not really. Empty vessels. But anyway. We are much more interested in what sprouts around, what develops about, in the augmentations of buildings, in the erections (of buildings), in poky little windows carved in walls crooked and twisted, where a door opens onto a room to reveal a woman sat heavily, selling old stuff, selling valuable stuff, selling - well - selling. Stuff. Since there is history here, you see, a theme in this area where we live, a penchant for collecting antiquities. It's everything you ever wanted to know about how picturesque south of the river can be, including that silly rule, the perpetual cause of tourist dismay, that tells the story of legalization - at a market of fleas - of what would have been stolen previously. After midnight...like all good tales of fright begin. And: before dawn. What you'd stolen you could sell here legally. Or so they say.

But we don't see the woman today. There is only a scaffolding blocking the street, and construction workers laying planks in place, blond. Wood, that is. So we move to the side and sometimes there are people to dodge, sometimes a parked car to avoid, but there is always that red-white-red strip that sticks to the eye, and the lights are always on, lantern-like. Except the nature of sex is of a different kind, it assaults the scaffolding when the weather is right, when muscles force themselves on an unsuspecting eye. Wolf whistles in reverse! Faux might.

So, on we go, past the park on the right - a gap between buildings more like - to meet a junction where we look back and forth, where we look left and right, until our head swivels on the rod of our spine and we can cross the road without a splat. But. The 
moment we cross, another restaurant arrives (Spanish! Tapas!) and another one opposite (French, mais oui!) and we are forced to face what there is, because this is where the street wriggles to court the eye - our poor, poor wandering eye - in a shift that makes our step slow down a bit every but every time we draw the picture in our mind, the picture that captures the event of the street in time.

The building is all color and repurposed light (like so many along this river's industrial side). But we won't go inside the fashion museum today, no. We will pass the building and only recall the woman responsible for it, who'd allowed fuchsia to spill out of her hair and onto the street, and the way she lives here and there but mostly there (pondacross that is) and all we'll ever know - we the little ones, we the insignificant ones, we the ones who only know the myths we live inside like echoes of times past, we the invisible people, the fully-visible-yet-impersonal people - is that there is no fashion for us today. Not today, not ever. We don't belong to it, not quite.

And right around the point where the pavement narrows to prevent us from taking flight and bodies are forced to negotiate proximity of buggies and bags, of heels and suits and flying, fluttering ties that pass by in choreographies of violence wound tight, right here an important man lives, who we met for the first time - was it at a party, was it drinks all round, was it in a café, a restaurant, that bar across the street? - we met a man who drinks and eats and overall consumes the street on which we live.

It's his street, in fact, not ours. It's his and his friends' and the developers' - the ones who live around the corner and wage wars on the twits of council. And it's a marriage made in urbane heaven - in urban village heaven that is - where fights are fought to conserve and retain, to have remain-as-is - as was, we should think - and all we know is what we are told, what we see when the man opens his mouth and we can confirm that it's all dust and carnivorous moths inside. This man of legality, preserved in aspic. And that's what it is, what sums up the journey inscribed on our skin, along this street of developers, judges and directors of advertising, which sooner or later we will have to leave. It will be as if it had never been ours. It will remain as it always has been, always in flux, always ascending, always scaling the hierarchy of places of interest in this town already crammed with treats. Estate agents on this street? Aplenty. 
Because this is the thing that demands saying: there is a railway bridge that cuts across the street. And once you've passed under it, once you've listened to the echo of trains rumbling, once you've walked through the mold of Victoriana dripping, you will find yourself on the other side. And everything is different on the Other Side. Because you are in glass-steel land now, you are there where angles angle mightily, where shapes are sharpened to assault space and carve it, claim right to it. That is where we end, where we realize why they call the spiky one by its name (Shhhhard!), why we're a breath away from where the first crossing over the river was ever made, where they bridged it for the first time. Where they - Romans, who else? - had set up camp on a grid. Colonizing.

But that is also where we get lost to our walk. The walk walks without us from here on, it abandons us to become its own thing. Because we were never truly on this street. We were merely summoned to haunt the place, to pretend that we could ever belong to it, we the eyes, we the heads, we the poor little hearts, the insignificant, fleeting things we who will only perish and die. Oh, we know. We were matter once and matter is what we'll be. Nothing is lost, what matters remains. But for now - but always? - the matter that was, is lost to the matter that surpasses. Us, it.

We will buy our groceries today. We will walk back, take the route the other way. We will enter the estate and take the lift, unlock the door, let go of our shopping. This strict, ordered arrangement of voids, this home we were instructed to buy, will always be ours for a blink. It was here before us, it will remain when we leave. Identical to itself when cast in another's eye, refashioned to fit a different body. This glove of bricks. It will remain mute, dumb. No voice for the flat, none. But by then no one will be here to care, not as we once did.

'Rest now,' the voice of authority says. 'Leave it.' 